\title{
Hypoxia and the cardiovascular response to dynamic knee-extensor exercise
}

\author{
MARIA D. KOSKOLOU, JOSÉ A. L. CALBET, GÖRAN RÅDEGRAN, AND ROBERT C. ROACH \\ The Copenhagen Muscle Research Centre, Rigshospitalet, DK-2200 Copenhagen, Denmark
}

Koskolou, Maria D., José A. L. Calbet, Göran Rådegran, and Robert C. Roach. Hypoxia and the cardiovascular response to dynamic knee-extensor exercise. Am. $J$. Physiol. 272 (Heart Circ. Physiol. 41): H2655-H2663, 1997.Hypoxia affects $\mathrm{O}_{2}$ transport and aerobic exercise capacity. In two previous studies, conflicting results have been reported regarding whether $\mathrm{O}_{2}$ delivery to the muscle is increased with hypoxia or whether there is a more efficient $\mathrm{O}_{2}$ extraction to allow for compensation of the decreased $\mathrm{O}_{2}$ availability at submaximal and maximal exercise. To reconcile this discrepancy, we measured limb blood flow (LBF), cardiac output, and $\mathrm{O}_{2}$ uptake during two-legged knee-extensor exercise in eight healthy young men. They completed studies at rest, at two submaximal workloads, and at peak effort under normoxia (inspired $\mathrm{O}_{2}$ fraction 0.21 ) and two levels of hypoxia (inspired $\mathrm{O}_{2}$ fractions 0.16 and 0.11 ). During submaximal exercise, LBF increased in hypoxia and compensated for the decrement in arterial $\mathrm{O}_{2}$ content. At peak effort, however, our subjects did not achieve a higher cardiac output or LBF. Thus $\mathrm{O}_{2}$ delivery was not maintained and peak power output and leg $\mathrm{O}_{2}$ uptake were reduced proportionately. These data are consistent then with the findings of an increased LBF to compensate for hypoxemia at submaximal exercise, but no such increase occurs at peak effort despite substantial cardiac capacity for an elevation in LBF.

arterial oxygen saturation; limb blood flow; stroke volume; lactate; potassium

IN STUDIES ON THE EFFECT of hypoxia on limb blood flow (LBF), Rowell et al. (18) concluded that, as long as the mass of active muscle is too small to tax the pumping capacity of the heart, vasodilatation and LBF can rise to higher values than those attained under normoxemia. The elevation can be of such a magnitude as to compensate, even in severe hypoxemia, for the lowered arterial $\mathrm{O}_{2}$ content $\left(\mathrm{Ca}_{\mathrm{O}_{2}}\right)$, not only at light to moderate exercise but also at intense exhaustive work. Thus Rowell et al. found that $\mathrm{O}_{2}$ delivery to the exercising muscle was maintained and similar peak muscle $\mathrm{O}_{2}$ uptake $\left(\dot{\mathrm{V}} \mathrm{O}_{2}\right)$ and power output values were achieved with hypoxemia. Richardson et al. (17), using the same exercise model, i.e., one-legged dynamic knee-extension exercise, found contradictory results: their endurancetrained subjects had similar LBFs under submaximal and lower LBFs under maximal exercise with hypoxia, resulting in decreased $\mathrm{O}_{2}$ delivery and peak power output. During submaximal work, $\mathrm{O}_{2}$ extraction was increased to compensate for the low $\mathrm{O}_{2}$ delivery in hypoxia but not at the exhaustive level. The subjects in this latter study were able to produce power outputs almost twice as high as those in the investigation by Rowell et al. (18). The training status may then be an explanatory factor for being able not only to produce a large arterially transported amount of $\mathrm{O}_{2}$ but also to better utilize this supply.

Neither study included measurement of cardiac output $(\mathrm{CO})$, but it has been repeatedly shown $(2,11,19$, 22 ) in ordinary bicycle exercise that $\mathrm{CO}$ is elevated by acute hypoxemia at a given submaximal $\mathrm{VO}_{2}$, whereas peak CO remains the same or is lower. If the submaximally elevated $\mathrm{CO}$ is not reflected in a higher blood flow to the exercising skeletal muscles, a larger fraction of the blood flow output of the heart must be directed to noncontracting tissues.

Our primary reason for performing this study was to elucidate why there was a difference in results between the studies of Rowell et al. (18) and Richardson et al. (17); i.e., whether during exercise a compensation is made for the arterial hypoxemia by elevation in the $\mathrm{O}_{2}$ delivery to the muscle or by a more efficient $\mathrm{O}_{2}$ extraction by the muscles and the possible role of aerobic training status. Another reason was to evaluate whether hypoxemia also induced an elevation in the $\mathrm{CO}$ when exercising with a smaller fraction of the muscle mass than that used in bicycling. The $\mathrm{CO}$ measurement enabled us to estimate blood flow and $\mathrm{O}_{2}$ extraction of nonexercising tissues and organs. Moreover, when exercising with only a small fraction of the muscle mass, it is apparent that a low $\mathrm{O}_{2}$ tension in the inspired air to some extent can be compensated for by an enlarged ventilation, minimizing the effect of arterial hypoxemia. Thus, to evaluate the extent to which this adaptation may occur, as well as the dependence of the circulatory response on the severity of hypoxia, we used an intermediate degree of hypoxia [inspired $\mathrm{O}_{2}$ fraction $\left(\mathrm{FI}_{\mathrm{O}_{2}}\right)$ 0.16] in addition to the one $\left(\mathrm{FI}_{\mathrm{O}_{2}} 0.11-0.12\right)$ used in the previous studies $(17,18)$.

\section{METHODS}

Subjects. Eight young men (aged 21-30 yr) participated in the study. Their maximal $\mathrm{O}_{2}$ uptake $\left(\dot{\mathrm{V}}_{\mathrm{O}_{2 m a x}}\right)$, as determined by ordinary two-legged bicycle exercise, varied between 41 and $70 \mathrm{ml} \cdot \mathrm{kg}^{-1} \cdot \mathrm{min}^{-1}$. Two of them were sedentary $(41$ $\left.\mathrm{ml} \cdot \mathrm{kg}^{-1} \cdot \mathrm{min}^{-1}\right)$, three were moderately active $(51 \mathrm{ml}$. $\left.\mathrm{kg}^{-1} \cdot \mathrm{min}^{-1}\right)$, and three were quite fit $\left(62-70 \mathrm{ml} \cdot \mathrm{kg}^{-1} \cdot \mathrm{min}^{-1}\right)$. The knee-extensor mass of one leg varied from 2.39 to $4.05 \mathrm{~kg}$, the capillary density varied from 266 to $491 \mathrm{cap} / \mathrm{mm}^{2}$, and the distribution of muscle fibers varied as follows: slow twitch, 42-72\%; fast-twitch type a, 17-38\%; and fast twitch type b, 9-28\% (Table 1). They were informed about the possible risks and discomfort associated with the experiments and volunteered to participate, giving their signed consent. The study had the approval of the Copenhagen Frederiksberg Ethical Committee.

Methodology. Pulmonary $\dot{\mathrm{V}}_{2}, \mathrm{CO}_{2}$ production, and ventilation $\left(\dot{V}_{E}\right)$ were measured with an on-line system (Medical Graphics CPX). The subjects breathed through a lowresistance breathing valve. In a few cases, expired air was collected in Douglas bags, and it was measured for volume 
Table 1. Physical characteristics of subjects

\begin{tabular}{|c|c|c|c|c|c|c|c|c|c|c|}
\hline \multirow{2}{*}{$\begin{array}{c}\text { Subject } \\
\text { No. }\end{array}$} & \multirow{2}{*}{$\begin{array}{l}\text { Age, } \\
\text { yr }\end{array}$} & \multirow{2}{*}{$\begin{array}{l}\text { Height, } \\
\text { cm }\end{array}$} & \multirow{2}{*}{$\begin{array}{l}\text { Weight, } \\
\text { kg }\end{array}$} & \multirow{2}{*}{$\begin{array}{c}\dot{\mathrm{V}} \mathrm{O}_{2 \max } \\
\mathrm{ml} \cdot \mathrm{kg}^{-1} \cdot \mathrm{min}^{-1}\end{array}$} & \multicolumn{3}{|c|}{ Fiber Type, \% } & \multirow{2}{*}{$\begin{array}{l}\text { Capillary } \\
\text { Density, } \\
\text { cap } / \mathrm{mm}^{2}\end{array}$} & \multirow{2}{*}{$\begin{array}{l}\text { Capillaries } \\
\text { per Fiber }\end{array}$} & \multirow{2}{*}{$\begin{array}{c}\text { Knee } \\
\text { Extensor } \\
\text { Mass, kg }\end{array}$} \\
\hline & & & & & ST & FTa & FTh & & & \\
\hline 1 & 30 & 185 & 78.3 & 70 & 55 & 36 & 9 & 433 & 2.8 & 3.03 \\
\hline 5 & 24 & 185 & 95.0 & 66 & 53 & 37 & 10 & 447 & 2.8 & 3.64 \\
\hline 2 & 22 & 184 & 81.0 & 62 & 65 & 22 & 13 & 491 & 2.9 & 3.04 \\
\hline 7 & 26 & 186 & 78.3 & 51 & 72 & 17 & 11 & 405 & 2.4 & 2.70 \\
\hline 8 & 23 & 170 & 68.2 & 51 & 48 & 34 & 18 & 448 & 2.4 & 2.39 \\
\hline 3 & 21 & 167 & 67.3 & 51 & 49 & 23 & 28 & 433 & 2.3 & 2.75 \\
\hline 4 & 24 & 185 & 93.3 & 41 & 44 & 38 & 18 & 350 & 3.0 & 4.01 \\
\hline 6 & 21 & 187 & 102.3 & 41 & 42 & 38 & 20 & 266 & 2.6 & 4.05 \\
\hline Mean $\pm \mathrm{SE}$ & $24 \pm 1$ & $181 \pm 3$ & $83 \pm 5$ & $54.1 \pm 3.8$ & $53.5 \pm 3.7$ & $30.6 \pm 3.0$ & $15.9 \pm 2.3$ & $409.1 \pm 24.9$ & $2.7 \pm 0.1$ & $3.2 \pm 0.2$ \\
\hline
\end{tabular}

$\dot{\mathrm{V}}_{2 \max }$, maximal $\mathrm{O}_{2}$ uptake; ST, slow twitch; FTa and FTb, fast twitch type a and b, respectively; cap, capillaries.

with a Tissot spirometer; concentrations of $\mathrm{O}_{2}$ and $\mathrm{CO}_{2}$ were measured with paramagnetic (Servomex) and infrared (Beckman LB-II) analyzers, respectively. Gases with known $\mathrm{O}_{2}$ and $\mathrm{CO}_{2}$ concentrations (micro-Scholander) were used for gas analyzer calibration.

$\mathrm{CO}$ was measured by the dye-dilution technique with indocyanine green dye [cardiogreen (CG); Becton-Dickinson, Cockeysville, MD] as a tracer. CG (4-8 mg depending on the exercise intensity) was injected into a peripheral vein, and arterial blood was withdrawn through a densitometer (Waters CO-10) at a constant rate of $22 \mathrm{ml} / \mathrm{min}$ by a withdrawal pump (Harvard 2202A). The withdrawn blood $(\sim 20 \mathrm{ml})$ was reinfused after each determination.

Blood pressure was continuously monitored by a transducer (Gould Electronics, P23) placed at the femoral level (mean distance below the heart $57 \mathrm{~cm}$ ). Mean arterial pressure (MAP) was estimated as two-thirds diastolic pressure plus one-third systolic pressure. Heart rate (HR) was obtained either from the continuously recorded electrocardiogram signal or from the pulsatile pressure curves.

LBF was measured in the femoral vein by the constantinfusion thermodilution technique as described in detail elsewhere (1). Briefly, ice-cold isotonic saline was infused into the femoral vein at a rate of $50-145 \mathrm{ml} / \mathrm{min}$ to obtain a drop of $-1.0^{\circ} \mathrm{C}$ in blood temperature as determined with a thermistor inserted in a venous catheter (TD probe 94-030-2.5F, Edwards Edslab). The temperature was continuously recorded (Gould recorder). Values for LBF were obtained with the heat balance equation of Andersen and Saltin (1). $\dot{V}_{2}$ of the knee extensors (leg $\dot{\mathrm{V}}_{2}$ ) was calculated as the product of the femoral venous blood flow and the time-matched value of femoral arteriovenous (a-v) $\mathrm{O}_{2}$ difference (Fick principle).

Hemoglobin concentration $([\mathrm{Hb}])$ and blood $\mathrm{O}_{2}$ saturation $\left(\mathrm{SO}_{2}\right)$ were measured with a $\mathrm{CO}$-oximeter (AVL $912 \mathrm{Co}-$ Oxylite). $\mathrm{PO}_{2}, \mathrm{PCO}_{2}$, and $\mathrm{pH}$ were determined with standard techniques (AVL Compact 2). Hematocrit determinations were made in triplicate with microcentrifugation. Femoral $\mathrm{Ca}_{\mathrm{O}_{2}}$ and venous $\mathrm{O}_{2}$ content $\left(\mathrm{Cv}_{\mathrm{O}_{2}}\right)$ were computed from the measured [Hb] and $\mathrm{So}_{2}$ [i.e., $\left(1.34[\mathrm{Hb}] \times \mathrm{So}_{2}\right)+(0.003 \times$ $\left.\left.\mathrm{PO}_{2}\right)\right]$. Plasma $\mathrm{K}^{+}$concentration $\left(\left[\mathrm{K}^{+}\right]\right)$was measured with ion-sensitive electrodes (AVL 983-S). Lactate concentrations were measured on whole blood with Triton $\mathrm{X}$ as an erythrocyte lysing agent (YSI 2300 Stat Plus).

To estimate quadriceps femoral muscle volume and mass for each subject, measurements of thigh length, multiple circumferences of the thigh, skinfold thickness, and calculated thigh volume were used (10). From muscle biopsies from the lateral portion of the knee extensors, the distribution of muscle fiber types was determined by staining for myofibrillar adenosinetriphosphatase after acidic and basic incuba- tion, and capillaries were visualized with periodic acid Schiff's staining or the use of an antibody (16).

Procedures. The subjects were studied under normoxia and when inspiring gas mixtures contained 16 and $11 \% \mathrm{O}_{2}$ in $\mathrm{N}_{2}$. The three experimental conditions were performed in random order and separated by at least $1 \mathrm{~h}$ of rest with the subjects in a half-recumbent position breathing room air. Despite the long resting period, in two cases, the lactate response in normoxia was affected by the preceding hypoxic condition, resulting in a lowering of blood lactate while exercising. Both cases were deleted in the treatment of blood lactate data (one at rest and two submaximal workloads and the other at all workloads).

Before the experimental day, the subjects reported to the laboratory and had a resting electrocardiogram and anthropometric measurements for the calculation of their thigh volume. They then practiced two-legged kicking exercise at several workloads and performed an incremental test for the determination of their peak workload $\left(\mathrm{WL}_{\text {peak }}\right)$ under normoxia and $\mathrm{FI}_{\mathrm{O}_{2}}$ 0.11. The $\mathrm{WL}_{\text {peak }}$ for $\mathrm{FI}_{\mathrm{O}_{2}} 0.16$ was estimated as $\sim 90 \%$ of the normoxic $\mathrm{WL}_{\text {peak }}$.

On the experimental day, one catheter was placed in the femoral artery and another in the femoral vein with the Seldinger technique for blood sampling, detection of CG (arterial), and determination of LBF (venous). Additionally, a venflon was placed in a vein in the left upper arm for the injection of CG dye. After placement of the catheters, the subjects were seated on the knee-extension ergometer and breathed through a two-way valve, inspiring the pertinent gas mixture. The exercise consisted of dynamic contractions of the knee-extensor muscles of the two legs at a rate of $1 \mathrm{~Hz}$ starting at $30 \mathrm{~W}$ for $\sim 5 \mathrm{~min}$ and continued at an intensity corresponding to $50 \%$ of the preestablished $\mathrm{WL}_{\text {peak }}$ for each condition $\left(\mathrm{WL}_{50}\right)$ for another $5 \mathrm{~min}$. After an $\sim 10$-min resting period (while breathing normoxic air and only at the last 2-3 min returning to inhaling the gas mixture), the subjects resumed exercise starting at $\mathrm{WL}_{50}$ and continuing at 75 and $90 \%$ of $\mathrm{WL}_{\text {peak }}$ for $2 \mathrm{~min}$ at each workload. From thereon, $5-\mathrm{W}$ increments were applied until the subjects achieved their maximal attainable workload (peak effort). Major efforts were made to encourage the subjects to attain their true peak performance under all conditions. Blood sampling and measurements of $\mathrm{LBF}$ and $\mathrm{CO}$ were performed with this sequence at rest, at the two submaximal workloads ( $30 \mathrm{~W}$ and $\mathrm{WL}_{50}$ ) under steady-state conditions, and at peak effort close to (within $\sim 1$ min) exhaustion. When possible, duplicate measurements of $\mathrm{LBF}$ and femoral a-v $\mathrm{O}_{2}$ differences were taken during the brief period of peak exercise. HR, MAP, pulmonary $\dot{\mathrm{V}} \mathrm{O}_{2}, \mathrm{CO}_{2}$ production, and $\mathrm{VE}$ values were also obtained during each condition. 
After at least $1 \mathrm{~h}$ of rest, the subjects performed an incremental cycling exercise protocol under normoxia for the determination of their pulmonary $\dot{\mathrm{VO}}_{2}$ and $\mathrm{CO}$ during maximal whole body exercise.

Statistics. Differences in the measured variables among conditions and exercise levels were analyzed with a paired $t$-test when only two comparisons were made and with a one-way analysis of variance for comparisons among the three conditions. Tukey's honestly significant difference test was used to assign specific differences in the analysis of variance. Significance was accepted at $P<0.05$. Data are reported as means $\pm \mathrm{SE}$.

\section{RESULTS}

Systemic response. At normoxia, arterial $\mathrm{PO}_{2}\left(\mathrm{~Pa}_{\mathrm{O}_{2}}\right)$ was $>90$ Torr in all subjects and at all exercise intensities. With the two levels of hypoxic gas mixtures, $\mathrm{Pa}_{\mathrm{O}_{2}}$ was reduced to 67-78 $\left(\mathrm{FI}_{\mathrm{O}_{2}} 0.16\right)$ and 37-46 Torr $\left(\mathrm{FI}_{\mathrm{O}_{2}}\right.$ 0.11; Fig. 1). Because of the profound elevation in ventilation at rest and all exercise levels, arterial $\mathrm{PCO}_{2}$ fell to 33,31 , and 27 Torr at peak exercise in the three conditions, respectively.
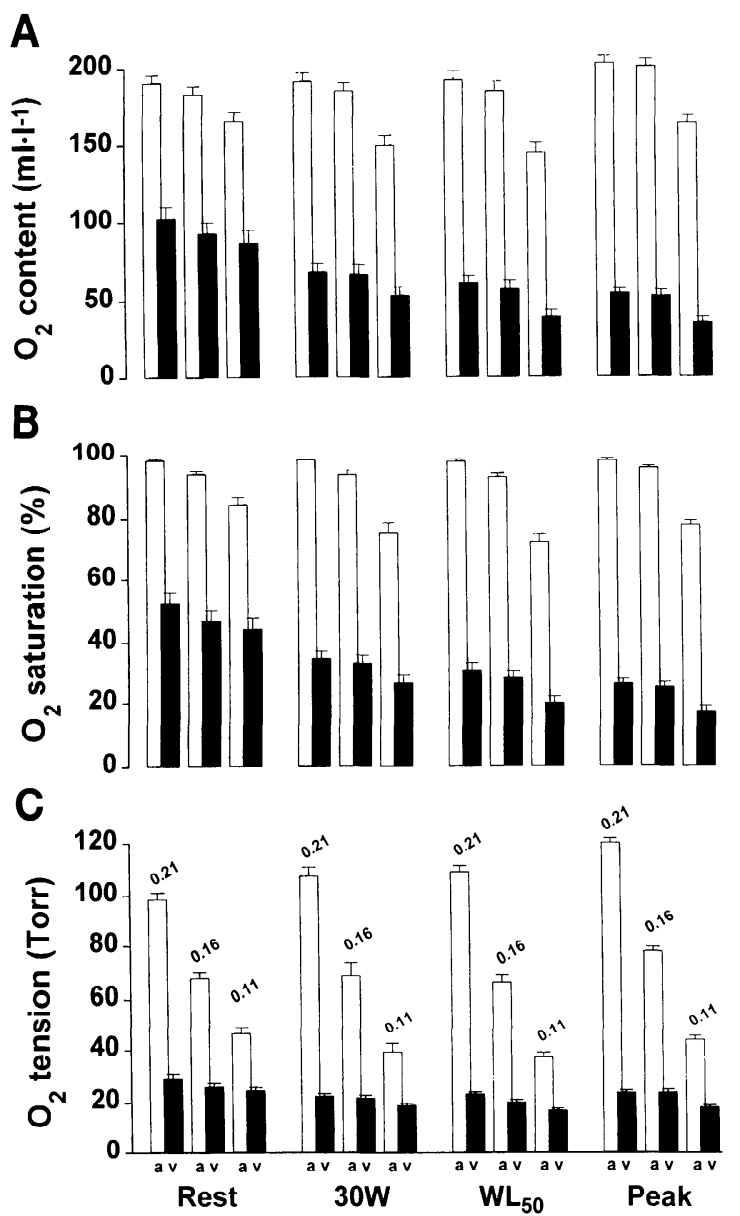

Fig. 1. $\mathrm{O}_{2}$ content $(A)$, saturation $(B)$, and tension $(C)$ in arterial (a) and femoral venous (v) blood for 8 subjects at inspired $\mathrm{O}_{2}$ fraction $\left(\mathrm{F}_{\mathrm{O}_{2}}\right)$ levels of $0.21,0.16$ and 0.11 at rest and while performing 2-legged dynamic knee-extensor exercise at $30 \mathrm{~W}$, at $50 \%$ of peak workload $\left(\mathrm{WL}_{50} ; 71 \pm 5,63 \pm 4\right.$, and $57 \pm 4 \mathrm{~W}$ for the $3 \mathrm{FI}_{\mathrm{O}_{2}}$ levels, respectively), and at peak effort $(139 \pm 10,127 \pm 10$, and $110 \pm 10 \mathrm{~W}$, respectively). Values are means $\pm \mathrm{SE}$
Arterial $\mathrm{So}_{2}\left(\mathrm{Sa}_{\mathrm{O}_{2}}\right)$ at normoxia was $\geq 93 \%$ in all subjects, with mean values $>95 \%$. At $\mathrm{Fi}_{\mathrm{O}_{2}} 0.16, \mathrm{Sa}_{\mathrm{O}_{2}}$ was lowered only slightly, but $\mathrm{Sa}_{\mathrm{O}_{2}}$ fell markedly at $\mathrm{FI}_{\mathrm{O}_{2}} 0.11\left(\mathrm{FI}_{\mathrm{O}_{2}} 0.16: 93.9 \pm 0.8,93.7 \pm 1.1,92.9 \pm\right.$ 1.0, and 95.5 $\pm 0.5 \% ; \mathrm{FI}_{\mathrm{O}_{2}} 0.11: 84.3 \pm 2.2,75.4 \pm 3.1$, $72.5 \pm 2.3$, and $77.9 \pm 1.2 \%$ at rest and the various exercise levels, respectively). [Hb] increased in all conditions from $145-146 \mathrm{~g} / \mathrm{l}$ at rest to $155-156 \mathrm{~g} / \mathrm{l}$ during peak exercise, which, in turn, increased the $\mathrm{Ca}_{\mathrm{O}_{2}}$. At $\mathrm{FI}_{\mathrm{O}_{2}}$ 0.16, $\mathrm{Ca}_{\mathrm{O}_{2}}$ increased from $\sim 185 \mathrm{ml} / \mathrm{l}$ at rest and submaximal exercise to $201 \mathrm{ml} / \mathrm{l}$ at peak effort. At $\mathrm{FI}_{\mathrm{O}_{2}}$ 0.11, mean $\mathrm{Ca}_{\mathrm{O}_{2}}$ during exercise was $\sim 20 \%$ lower than in normoxia, with the smallest reduction at peak exercise.

The reduced $\mathrm{Ca}_{\mathrm{O}_{2}}$ resulted in peak power outputs being $\sim 10$ and $20 \%$ lower than normoxia at $\mathrm{FI}_{\mathrm{O}_{2}} 0.16$ and $\mathrm{FI}_{\mathrm{O}_{2}} 0.11$, respectively (Fig. 1). Pulmonary $\mathrm{VO}_{2}$ was maintained at rest and the submaximal workloads, taking the power outputs into account $(P>0.05)$. At peak effort, $\dot{\mathrm{VO}}_{2}$ was $2.7 \pm 0.13 \mathrm{l} / \mathrm{min}$ at normoxia and was reduced at both levels of hypoxia $(2.5 \pm 0.15 \mathrm{l} / \mathrm{min}$ at $\mathrm{FI}_{\mathrm{O}_{2}} 0.16$ and $2.1 \pm 0.13 \mathrm{l} / \mathrm{min}$ at $\mathrm{FI}_{\mathrm{O}_{2}} 0.16 ; P<0.05$ ). For comparison, the subjects' ${ }^{\mathrm{V}} \mathrm{O}_{2 \max }$, determined under normoxic bicycling, averaged $4.3 \pm 0.4 \mathrm{l} / \mathrm{min}$.

Pulmonary $\dot{V}_{\mathrm{E}}$ was elevated in relation to the degree of hypoxemia and exercise intensity mostly due to changes in tidal volume. $\dot{V}_{E}$ during exercise, as evidenced by the ventilatory coefficient $\left(\dot{\mathrm{VE}} / \dot{\mathrm{V}}_{2}\right)$, was increased only by the more severe hypoxic stimulus $\left(\mathrm{FI}_{\mathrm{O}_{2}}\right.$ 0.11) at the submaximal workloads $(P<0.05)$ but by both levels of lowered $\mathrm{PO}_{2}$ at peak effort, reaching levels of 48.3 and 60.2 at $\mathrm{FI}_{\mathrm{O}_{2}} 0.16$ and $\mathrm{FI}_{\mathrm{O}_{2}}$ 0.11, respectively.

CO was $3-7 \%$ higher with hypoxia at rest and at $30 \mathrm{~W}$. At $\mathrm{WL}_{50}\left(63 \mathrm{~W}\right.$ at $\mathrm{FI}_{\mathrm{O}_{2}} 0.16$ and $57 \mathrm{~W}$ at $\left.\mathrm{FI}_{\mathrm{O}_{2}} 0.11\right)$, the $\mathrm{CO}$-to- $\mathrm{V}_{2}$ ratio was the same as that in normoxia ( $\sim 11 \mathrm{l} / \mathrm{min})$, and this was also the case at peak effort $(\sim 8 \mathrm{l} / \mathrm{min})$, resulting in a peak $\mathrm{CO}$ of $19.9,18.7$, and $17.6 \mathrm{l} / \mathrm{min}$ at the three levels of arterial oxygenation, respectively (Fig. 2). Thus the observed elevation in $\mathrm{CO}$ by peak exercise per liter $\mathrm{O}_{2}$ was similar in the three conditions. The maximal $\mathrm{CO}$ of the subjects under normoxic ordinary bicycle exercise was $24.9 \mathrm{l} / \mathrm{min}$.

The HR response tended to be higher at rest and at $30 \mathrm{~W}$ the lower the $\mathrm{FI}_{\mathrm{O}_{2}}$ (Fig. 2). At $\mathrm{WL}_{50}$, $\mathrm{HR}$ was higher with hypoxia, taking the $\dot{\mathrm{V}}_{2}$ per workload into account. At peak effort, the HR was 157-158 beats/min at the three levels of arterial oxygenation, which is $\sim 20$ beats/min lower than in ordinary maximal bicycle work for these subjects.

Stroke volume (SV) was similar at rest and at $30 \mathrm{~W}$ among conditions but was significantly lower $(\sim 15 \mathrm{ml})$ at $\mathrm{FI}_{\mathrm{O}_{2}} 0.11$ during $\mathrm{WL}_{50}$ and at peak effort (Fig. 2). The $\mathrm{SV}$ during the more intense exercise in normoxia was 125-130 ml, which was similar to what was observed during submaximal and maximal ordinary bicycle exercise in normoxia.

MAP was maintained at similar levels regardless of the level of arterial oxygenation both at rest and during exercise. Total peripheral conductance varied slightly 
A
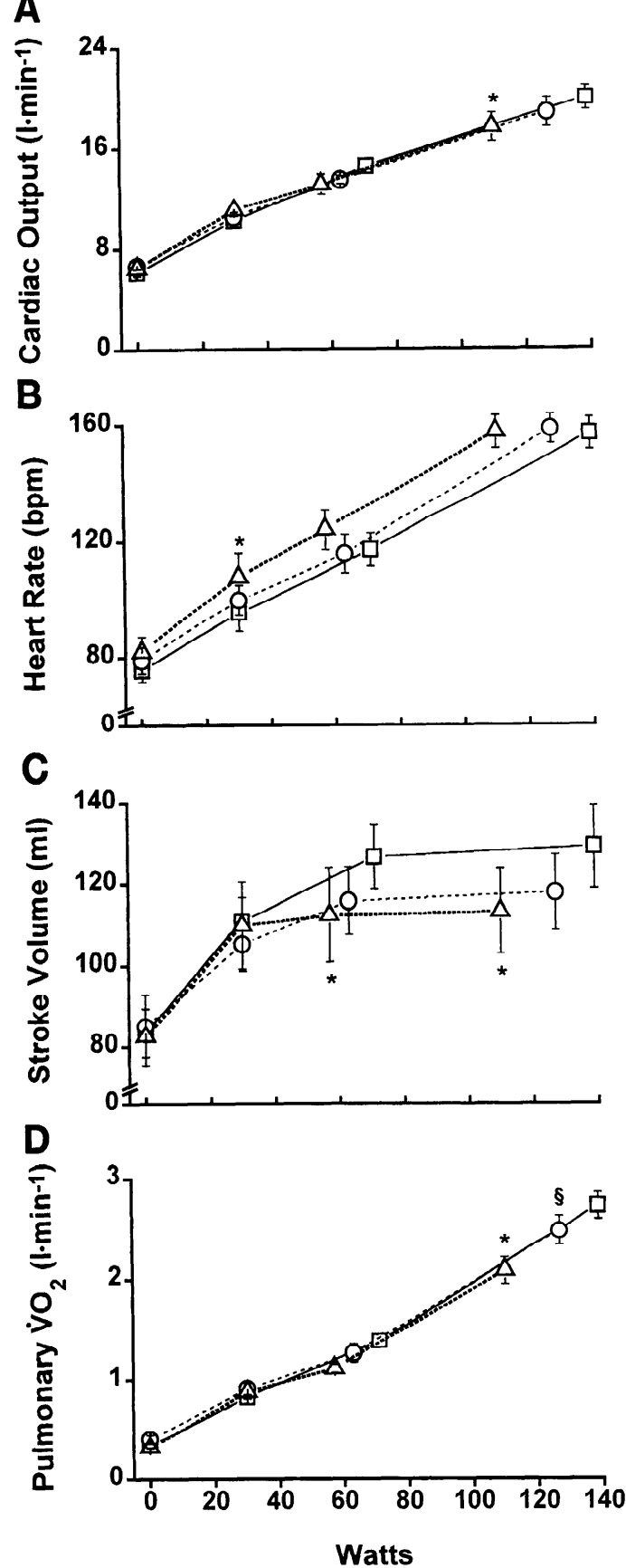

Fig. 2. Systemic cardiovascular responses [cardiac output $(A)$, heart rate $(B)$, and stroke volume $(C)]$ and $\mathrm{O}_{2}$ uptake $\left(\mathrm{V}_{2} ; D\right)$ to the 3 inspired gas mixtures $\left[\mathrm{FI}_{\mathrm{O}_{2}} 0.21\right.$ (口), $\mathrm{FI}_{\mathrm{O}_{2}} 0.16(O)$, and $\mathrm{FI}_{\mathrm{O}_{2}}$ $0.11(\triangle)$ ] at rest and during exercise, including peak effort. bpm, Beats/min. Values are means \pm SE. Significantly different $(P<0.05)$ for: $\S \mathrm{FI}_{\mathrm{O}_{2}} 0.21$ vs. $\mathrm{FI}_{\mathrm{O}_{2}} 0.16$; ${ }^{*} \mathrm{FI}_{\mathrm{O}_{2}} 0.21$ vs. $\mathrm{FI}_{\mathrm{O}_{2}} 0.11$.

among conditions at comparable exercise levels, but no systemic effect of hypoxia was observed.

Systemic $\mathrm{O}_{2}$ delivery was maintained with hypoxemia at rest, $30 \mathrm{~W}$, and $\mathrm{WL}_{50}$ at $\mathrm{FI}_{\mathrm{O}_{2}} 0.16$ but not fully at $\mathrm{FI}_{\mathrm{O}_{2}}$ 0.11. At peak effort, it was reduced as a function of the lowered peak power output.

Regional response. LBF was not affected either at rest or at the two submaximal workloads at $\mathrm{FI}_{\mathrm{O}_{2}} 0.16$, whereas a profound elevation was observed at $\mathrm{FI}_{\mathrm{O}_{2}}$ 0.11, amounting to an increase of $\sim 20-25 \%$ at rest $(P<0.01)$ and at submaximal exercise. The peak workload followed the drop in arterial oxygenation, and $\mathrm{LBF}$ was reduced accordingly $\left(6.7,6.3\right.$, and $6.0 \mathrm{l} / \mathrm{min}$ at $\mathrm{F}_{\mathrm{O}_{2}}$ $0.21,0.16$, and 0.11 , respectively; Fig. 3). However, $\mathrm{LBF}$ per watt was higher at $\mathrm{FI}_{\mathrm{O}_{2}} 0.11(P<0.05)$ and tended to be elevated at $\mathrm{FI}_{\mathrm{O}_{2}} 0.16$. During exercise at $30 \mathrm{~W}$, two-legged LBF was 47,50 , and $60 \%$ of $\mathrm{CO}$ at $\mathrm{Fi}_{\mathrm{O}_{2}} 0.21,0.16$, and 0.11 , respectively. At $\mathrm{WL}_{50}$, two-legged LBF was 55, 58, and $66 \%$ and at peak effort was 68,63 , and $70 \%$ of $\mathrm{CO}$ for $\mathrm{FI}_{\mathrm{O}_{2}} 0.21,0.16$, and 0.11 , respectively.
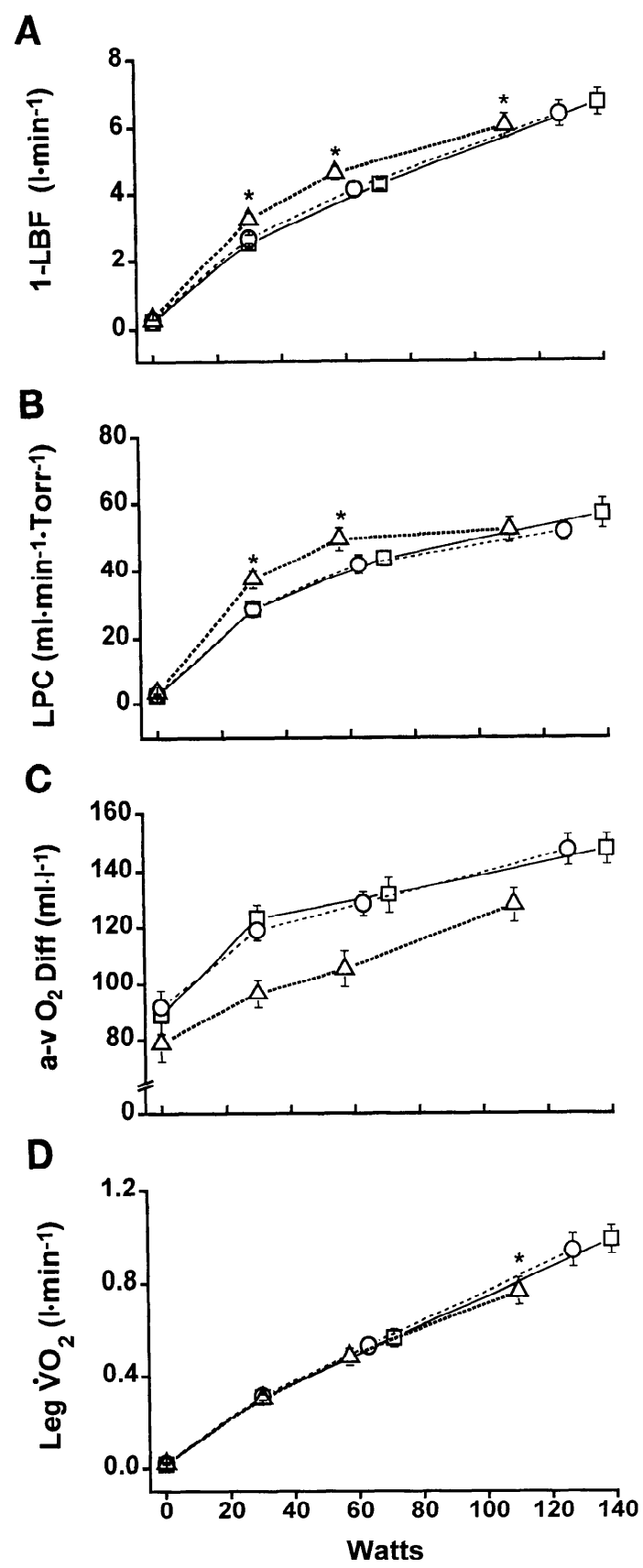

Fig. 3. Estimated 1-leg blood flow (1-LBF; $A$ ), limb peripheral conductance (LPC; $B$ ), femoral arteriovenous $\mathrm{O}_{2}$ difference $\left(\mathrm{a}-\mathrm{v} \mathrm{O}_{2}\right.$ Diff; $C$ ), and leg $\dot{\mathrm{VO}}_{2}(D)$ at rest and during exercise at $\mathrm{F}_{\mathrm{I}_{2}} 0.21(\square)$, $\mathrm{FI}_{\mathrm{O}_{2}} 0.16(O)$, and $\mathrm{FI}_{\mathrm{O}_{2}} 0.11(\triangle)$. $* P<0.05$ for $\mathrm{FI}_{\mathrm{O}_{2}} 0.21$ vs. $\mathrm{FI}_{\mathrm{O}_{2}} 0.11$ 
Limb peripheral conductance increased with the exercise intensity. During submaximal exercise, it was unaltered with $\mathrm{Fi}_{\mathrm{O}_{2}} 0.16$ but was markedly elevated with $\mathrm{FI}_{\mathrm{O}_{2}} 0.11(P<0.01)$, whereas at maximal exercise, it was unaltered at both $\mathrm{FI}_{\mathrm{O}_{2}}$ levels (Fig. 3).

Leg $\mathrm{O}_{2}$ delivery was maintained at rest and at $30 \mathrm{~W}$ with both levels of hypoxia. This was also the case at $\mathrm{WL}_{50}$ and at peak effort, taking the power output into account. In absolute numbers, the reduction in leg $\mathrm{O}_{2}$ delivery ranged from 7 to $28 \%$.

Lowering the $\mathrm{Ca}_{\mathrm{O}_{2}}$ caused a similar drop in venous $\mathrm{O}_{2}$ indexes because the percentage of $\mathrm{O}_{2}$ extraction amounted to $64 \%$ of the delivered $\mathrm{O}_{2}$ at $30 \mathrm{~W}$ in all conditions. It increased to 68,69 , and $72 \%$ at $\mathrm{WL}_{50}$ at $\mathrm{FI}_{\mathrm{O}_{2}} 0.21,0.16$, and 0.11 , respectively. At peak effort, the corresponding values were 73,73 , and $78 \%$. This resulted in a reduced femoral a-v $\mathrm{O}_{2}$ difference at all work levels, with the reductions being negligible at $\mathrm{FI}_{\mathrm{O}_{2}} 0.16$ but large at $\mathrm{FI}_{\mathrm{O}_{2}} 0.11(\sim 20 \%$ at submaximal workload and $14 \%$ at peak effort).

The femoral venous $\mathrm{So}_{2}$ was lower the higher the power output and the more marked the hypoxemia (Fig. 1). However, at peak effort and $\mathrm{FI}_{\mathrm{O}_{2}} 0.11$ the femoral venous $\mathrm{So}_{2}$ was still as high as $17 \%$ and the femoral $\mathrm{Cv}_{\mathrm{O}_{2}}$ was $36 \mathrm{ml} / 1$. This means that sizable amounts of $\mathrm{O}_{2}$ were left in the femoral vein blood at the different exercise levels and conditions. The femoral venous $\mathrm{PO}_{2}$ was 23-24 Torr in normoxia at the different workloads and $0-3$ Torr lower at $\mathrm{FI}_{\mathrm{O}_{2}} 0.16$ and $\mathrm{FI}_{\mathrm{O}_{2}}$ 0.11 .

Leg $\dot{\mathrm{V}}_{2}$ was maintained at rest and at $30 \mathrm{~W}$ in all three conditions. At the higher workloads, the absolute values were lowered in relation to the workload. The peak leg $\dot{\mathrm{V}}_{2}$ values were $0.98,0.94$, and $0.77 \mathrm{l} / \mathrm{min}$ for $\mathrm{FI}_{\mathrm{O}_{2}} 0.21,0.16$, and 0.11 , respectively. At peak effort in hypoxia $\left(\mathrm{FI}_{\mathrm{O}_{2}}\right.$ 0.11), two-legged $\mathrm{V}_{2}$ amounted to $\sim 75 \%$ of the pulmonary $\mathrm{Vo}_{2}$ at normoxia.

The lactate release was small at rest and at $30 \mathrm{~W}$ in all conditions and did not increase until the higher workloads when hypoxemia tended to cause a large release (Fig. 4). The femoral venous lactate concentration tended to be higher at submaximal and peak exercise with increasing levels of hypoxia, but it was significantly elevated only at $\mathrm{FI}_{\mathrm{O}_{2}} 0.11$ at the two higher workloads $(P<0.05)$. The values attained at peak workload were $5.6,5.7$, and $7.3 \mathrm{mmol} / \mathrm{l}$ at the three $\mathrm{FI}_{\mathrm{O}_{2}}$ levels, respectively. The arterial lactate values were lower than the venous values by $0.2-0.3 \mathrm{mmol} / \mathrm{l}$ at submaximal and by $\sim 1-1.5 \mathrm{mmol} / \mathrm{l}$ at peak exercise.

Femoral venous $\mathrm{pH}$ followed the changes in lactate concentration and femoral venous $\mathrm{PCO}_{2}\left(\mathrm{Pfv}_{\mathrm{CO}_{2}}\right)$ and reached at peak effort 7.17, 7.17 and 7.20 at $\mathrm{FI}_{\mathrm{O}_{2}}$ 0.21, 0.16 and 0.11 , respectively. The arterial $\mathrm{pH}$ was always higher compared with the venous $\mathrm{pH}$ by $\sim 0.07$ during submaximal work and by $\sim 0.16$ at peak effort.

The arterial $\left[\mathrm{K}^{+}\right]$increased in all conditions with increasing work (Fig. 5A), and the values reached at peak effort were similar in normoxia $(6.0 \pm 0.2 \mathrm{mmol} / \mathrm{l})$, $\mathrm{FI}_{\mathrm{O}_{2}} 0.16(5.7 \pm 0.1 \mathrm{mmol} / \mathrm{)})$, and $\mathrm{FI}_{\mathrm{O}_{2}} 0.11(5.6 \pm 0.1$
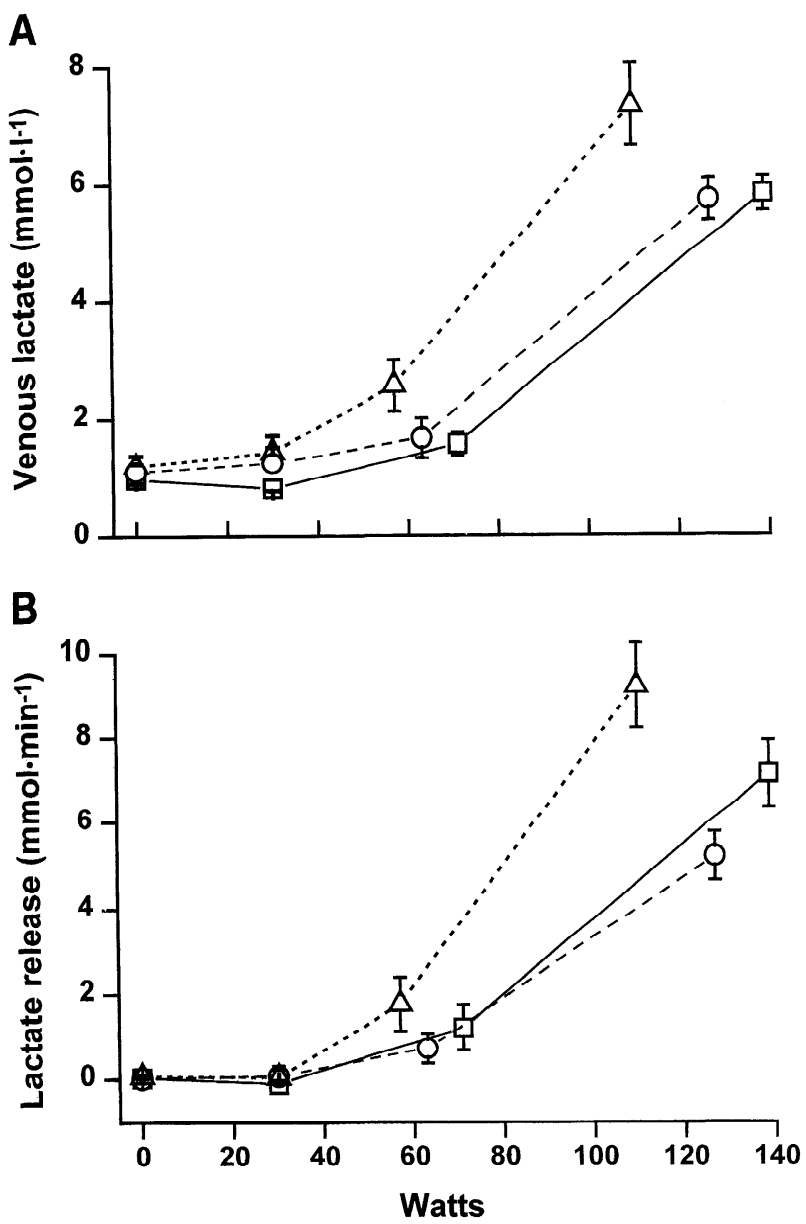

Fig. 4. Venous concentration of lactate $(A)$ and its release $(B)$ from 1 leg at the 3 inspired gas mixtures. $\square, \mathrm{FI}_{\mathrm{O}_{2}} 0.21 ; \bigcirc, \mathrm{FI}_{\mathrm{O}_{2}} 0.16 ; \triangle, \mathrm{FI}_{\mathrm{O}_{2}}$ 0.11 .

$\mathrm{mmol} / \mathrm{l}$ ) despite the lower workloads at peak effort in hypoxia (Fig. $5 B$ ).

The subjects were chosen to represent different training statuses, and their exercise capacity varied accordingly, although the least trained subjects had surprisingly high peak leg $\mathrm{VO}_{2}$. The explanation is that these two subjects were big and had a large knee-extensor muscle mass. When expressed as the leg $\dot{\mathrm{V}}_{2}$ per unit muscle mass, the training difference becomes quite marked. Fiber type composition on the muscle level also revealed the difference in training status, with the untrained subjects having more type IIb fibers (Table 1 ). Various indexes of muscle capillarization also followed training level. The high number of capillaries per fiber found in the untrained subjects is due to their having an extremely large muscle fiber size.

\section{DISCUSSION}

This study set out to resolve contradictory findings by two groups of investigators using basically the same paradigm for studying the acute response to hypoxemia when exercising with a small fraction of the whole body muscle mass. Our data confirm those of Rowell et al. (18) at submaximal exercises, i.e., an elevation in $\mathrm{LBF}$ to compensate for a lower $\mathrm{Ca}_{\mathrm{O}_{2}}$. At peak effort, 
A
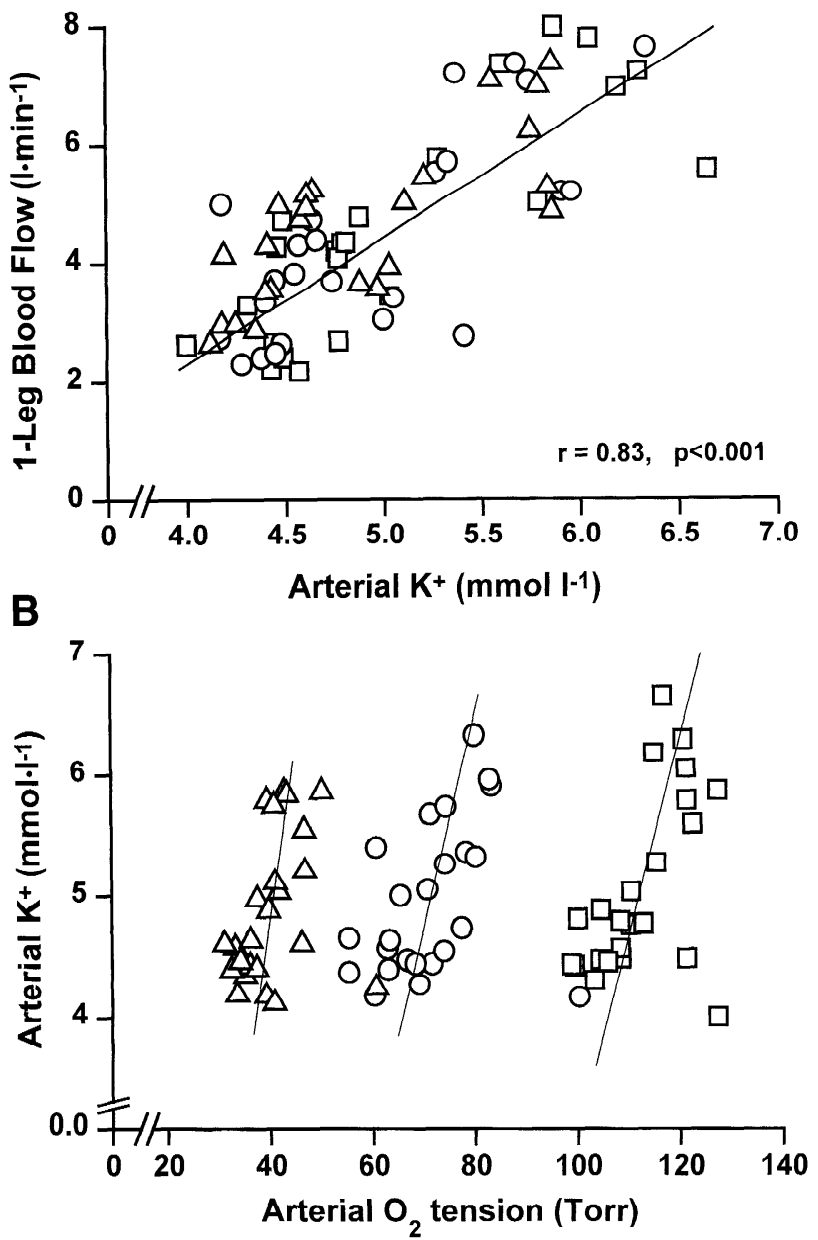

Fig. 5. $A$ : arterial $\mathrm{K}^{+}$is shown increasing as $1-\mathrm{LBF}$ increases in the 3 conditions at submaximal and peak effort. $B$ : similarity of $\mathrm{PO}_{2}$ to arterial $\mathrm{K}^{+}$relationship for all 3 conditions. $\square, \mathrm{FI}_{\mathrm{O}_{2}} 0.21 ; \mathrm{O}, \mathrm{FI}_{\mathrm{O}_{2}} 0.16$; $\triangle, \mathrm{FI}_{\mathrm{O}_{2}}$ 0.11. Note that $\mathrm{K}^{+}$values for $\mathrm{Fi}_{\mathrm{O}_{2}} 0.11$ are similar to $\mathrm{FI}_{\mathrm{O}_{2}} 0.16$ and normoxia despite significantly lower workloads at $\mathrm{WL}_{50}$ and peak effort.

our subjects failed to maintain $\mathrm{O}_{2}$ delivery at any of the hypoxemic conditions because they could not achieve higher LBFs. Femoral a-v $\mathrm{O}_{2}$ difference was not elevated either, and, as a result, the $\dot{\mathrm{V}}_{2}$ and power output were impaired. These data resemble the observations of Richardson et al. (17). The most likely reason for the contrasting results of Rowell et al. (18) at peak exercise (LBF increased, $\dot{\mathrm{V}}_{2}$ and power output unaltered) is that the exercise conditions in normoxia were not optimized for their subjects to achieve peak power outputs. A preset load was used, and although it was intense, upward adjustments of the work rate were not done to reach the highest attainable power output at the normoxic or hypoxic condition. The low femoral a-v $\mathrm{O}_{2}$ differences observed at peak effort by Rowell et al. (18) compared with ours and those of Richardson et al. (17) (Fig. 6) provide additional support to the above explanation. Thus the conclusion by Rowell et al. that muscle perfusion is "without an apparent limit" (Ref. 18 , p. H1038) is not valid for small muscle groups exercising, at least not for one- or two-legged knee extension when only $2-6 \mathrm{~kg}$ of muscle mass is engaged in the exercise.

Expressing the LBF response per watt under normoxia and hypoxia in the three studies demonstrated that the hypoxic stimulus significantly enhanced the $\mathrm{LBF}$ response at submaximal exercise (Fig. 6). It is noteworthy that included in Fig. 6 are the results from all three studies, i.e., Rowell et al. (18), Richardson et al. (17), and the present study. Thus our conclusion with regard to hypoxia, $\mathrm{LBF}$, and submaximal work is different from the conclusion that was drawn by Richardson et al. (17) from their data. The explanation is that Richardson et al. primarily analyzed their submaximal data in relation to the relative exercise load. This will not do when the peak power output is reduced as it is with hypoxia. $\mathrm{LBF}$ and $\mathrm{VO}_{2}$ are functions of the absolute work performed.

Low $\mathrm{Pa}_{\mathrm{O}_{2}}$ elicits enhanced cardiovascular responses that include vasodilatation of the periphery. Hypoxia acts primarily through reflexes originating in the peripheral chemoreceptors, but the direct effects of central nervous system hypoxia on cardiovascular function have been demonstrated in animals and several factors influence peripheral vasodilatation through local responses to tissue hypoxia. Marshall (14) and Skinner
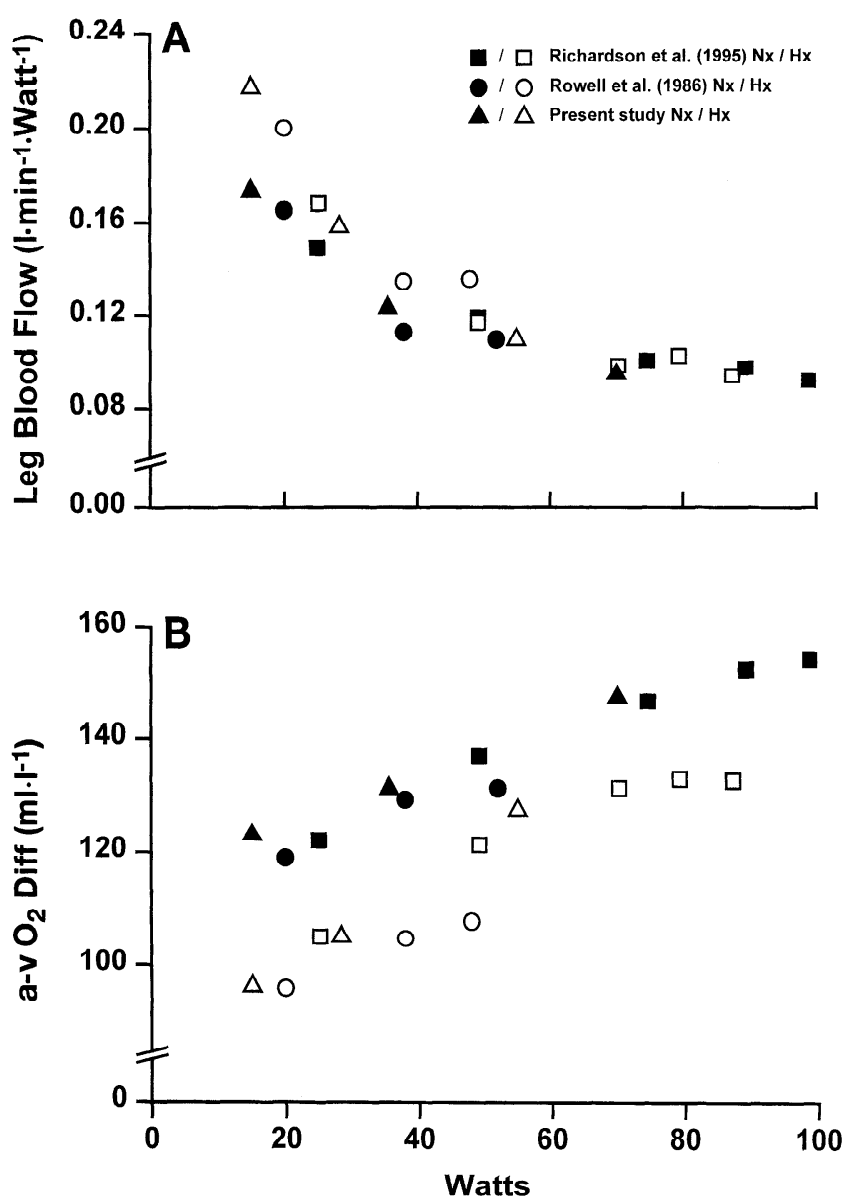

Fig. 6. Comparison ( $\mathrm{FI}_{\mathrm{O}_{2}}$ 0.21, rectangles; and $\mathrm{FI}_{\mathrm{O}_{2}}$ 0.11, triangles) of present data with those of Rowell et al. (18) and Richardson et al. (17) in regard to blood flow normalized for power output $(A)$ and $\mathrm{O}_{2}$ extraction over exercising leg (a-v $\mathrm{O}_{2}$ Diff; $\left.B\right)$. Nx, normoxia; $\mathrm{Hx}$, hypoxia. Circles, $\mathrm{FI}_{\mathrm{O}_{2}} 0.16$. 
and Marshall (21) have proposed adenosine as a peripheral vasodilator particularly responsive to hypoxia and acting primarily through an enhanced release of $\mathrm{K}^{+}$ from the muscle fiber and elevation of the interstitial $\left[\mathrm{K}^{+}\right]$. In our study, we cannot demonstrate a significant difference in $\left[\mathrm{K}^{+}\right]$between hypoxia and normoxia. We did, however, find that arterial $\left[\mathrm{K}^{+}\right]$was strongly related to $\mathrm{LBF}$ such that the higher the $\left[\mathrm{K}^{+}\right]$, the higher the LBF across all conditions $(r=0.8 ; P<0.001$; Fig. 5A). It is important to note that lower peak workloads at $\mathrm{Fl}_{\mathrm{O}_{2}} 0.11$ resulted in $\left[\mathrm{K}^{+}\right]$values similar to those seen at higher workloads in normoxia (Fig. $5 B$ ). This suggests a similar muscle fiber recruitment in normoxia and hypoxia because it is a key determinant of the net release of $\mathrm{K}^{+}$from the muscle fiber, or, as suggested by Skinner and Marshall, the adenosinesensitive $\mathrm{K}^{+}$channels are opened by high adenosine concentrations in hypoxia (21).

Recently, a $\mathrm{Po}_{2}$-sensitive cytochrome $P$-450 enzyme has been identified that forms the arachidonic acid metabolite 20-hydroxy-eicosatetraenoic acid (20-HETE) as a function of $\mathrm{PO}_{2}$ (8). 20-HETE is a potent vasoconstrictor in all animal systems tested (rat renal, cerebral and striated muscle beds). Almost no 20-HETE is formed at a $\mathrm{PO}_{2}$ of 40 Torr, with a linear increase in 20 -HETE formation of $100 \%$ at a $\mathrm{Po}_{2}$ of 140 Torr. It is unlikely, however, that this mechanism can account for the lack of increase in LBF at peak exercise in our study at $\mathrm{FI}_{\mathrm{O}_{2}} 0.11$ because the $\mathrm{Pa}_{\mathrm{O}_{2}}$ was consistently lower in both hypoxic conditions throughout exercise. One feature of the two-legged knee-extension model for hypoxia studies is that a marked hyperventilation at the peak workloads causes an increase in $\mathrm{Pa}_{\mathrm{O}_{2}}$; for example, at $\mathrm{FI}_{\mathrm{O}_{2}}$ 0.11, the $\mathrm{Pa}_{\mathrm{O}_{2}}$ increased from 37.4 Torr at $\mathrm{WL}_{50}$ to $43.9 \pm 1.3$ Torr at peak effort. We are left, however, with an inability to account for why there is a decrement in $\mathrm{LBF}$ at peak effort at $\mathrm{FI}_{\mathrm{O}_{2}} 0.11$. It is noteworthy that, when expressed per watt, $\mathrm{LBF}$ is slightly higher with hypoxia in this and the other two studies $(17,18)$ but not to such an extent that it could compensate for the lowered $\mathrm{Ca}_{\mathrm{O}_{2}}$.

Although further vasodilatation could not be achieved at peak effort, why did blood pressure not rise to facilitate a further increase in LBF by enhancing perfusion pressure? Rowell et al. (18) observed unchanged blood pressure with hypoxemia, but their subjects reached higher MAP values at peak exercise than in the present study. This probably relates to the difference in muscle mass engaged in the two studies because, in ordinary bicycle exercise, blood pressure was even lower. However, regardless of muscle mass involvement, it appears that hypoxia per se does not affect blood pressure during exercise. This brings up the question of what happens with nonleg blood flow during this type of exercise and the possible effect of hypoxemia. During submaximal exercise performing two-legged kicking, nonleg tissue blood flow is unaltered in normoxia, with only a tendency for a reduction at both levels of hypoxia. During peak effort, nonleg blood flow is higher than during the submaximal exercise and even compared with rest. Nonleg $\mathrm{V}_{2}$ is also elevated, reflecting that nonleg muscles become involved in the exercise to stabilize the hip region for the most intense work to be performed (Fig. 7). When the blood flow to the nonleg muscles is adjusted for being activated, it appears that noncontracting tissue blood flow is reduced at peak effort (Fig. 7).

Another interesting finding in our study is that the amount of $\mathrm{O}_{2}$ left in the femoral vein is high, even at peak effort at $\mathrm{Fi}_{\mathrm{O}_{2}} 0.11$, when it was $36.2 \mathrm{ml} / \mathrm{l}$ with a venous $\mathrm{PO}_{2}$ of 18.4 Torr. Even higher values were observed by Rowell et al. (18), but Richardson et al. (17) found a mean femoral $\mathrm{Cv}_{\mathrm{O}_{2}}$ to be $15 \mathrm{ml} / \mathrm{l}$ lower. This does not necessarily mean that their subjects exercised harder or that they were more trained because there is a close coupling between $\mathrm{Ca}_{\mathrm{O}_{2}}$ and femoral a-v $\mathrm{O}_{2}$ difference regardless of $\mathrm{Pa}_{\mathrm{O}_{2}}$ (Fig. 8). The subjects in the study by Richardson et al. (17) had, at peak effort and hypoxia, $5 \mathrm{ml} / 1$ lower $\mathrm{Ca}_{\mathrm{O}_{2}}$ than in the present study and that by Rowell et al. (18). We chose our subjects to represent different aerobic training statuses. Although the subgroups are small, the findings within them are consistent, and they do not support that the training status is a major factor in
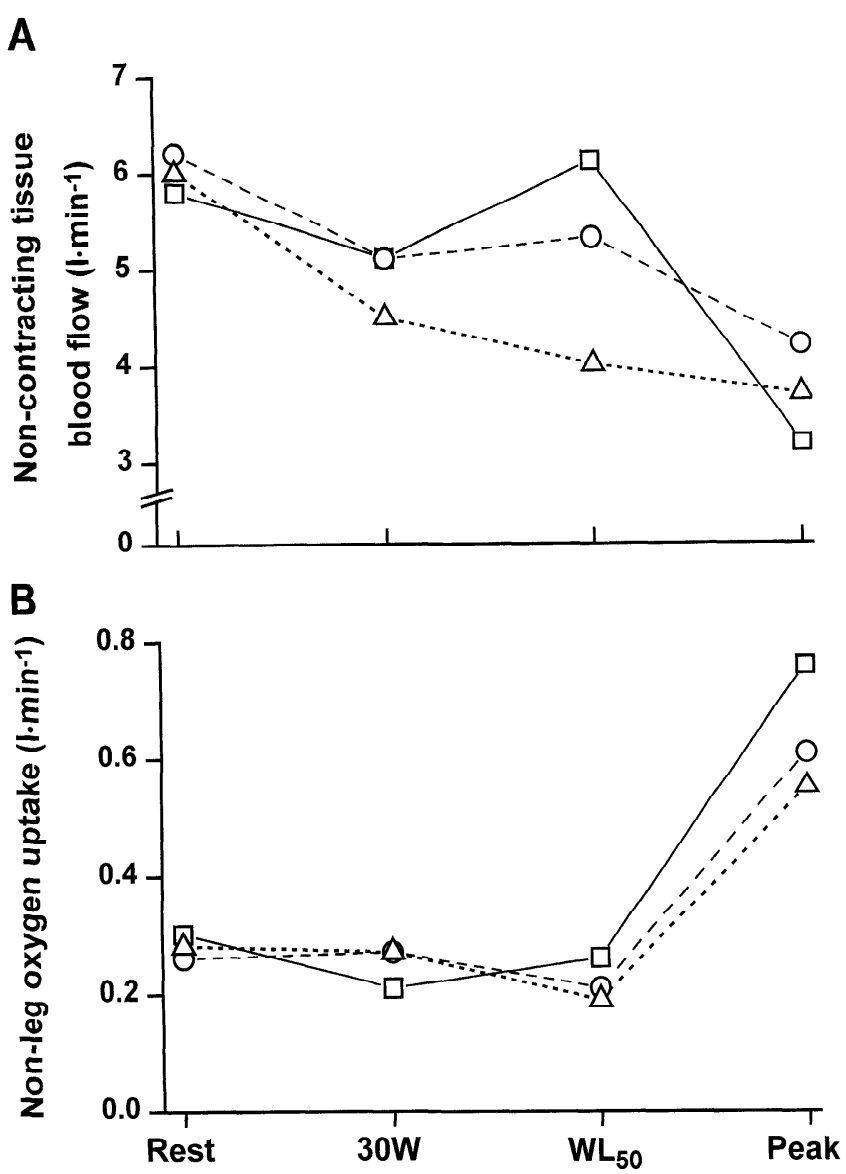

Fig. 7. A: estimated blood flow to organs and tissues that are not contracting (noncontracting tissue blood flow). $B$ : nonleg $\dot{\mathrm{V}}_{2}$ estimated by subtracting (leg $\mathrm{VO}_{2} \times 2$ ) from pulmonary $\dot{\mathrm{VO}}_{2}$. $\square, \mathrm{FI}_{\mathrm{O}_{2}} 0.21$; $\mathrm{O}$, $\mathrm{FI}_{\mathrm{O}_{2}}$ 0.16; $\triangle, \mathrm{FI}_{\mathrm{O}_{2}}$ 0.11. Pulmonary $\dot{\mathrm{V}}_{\mathrm{O}_{2}}$ at rest is subtracted from nonleg $\dot{\mathrm{V}}_{2}$ at peak effort and divided by observed femoral a-v $\mathrm{O}_{2}$ Diff to obtain estimated blood flow to supporting muscles in hip region. This blood flow is then subtracted from nonleg blood flow to obtain estimate of noncontracting tissue blood flow. 


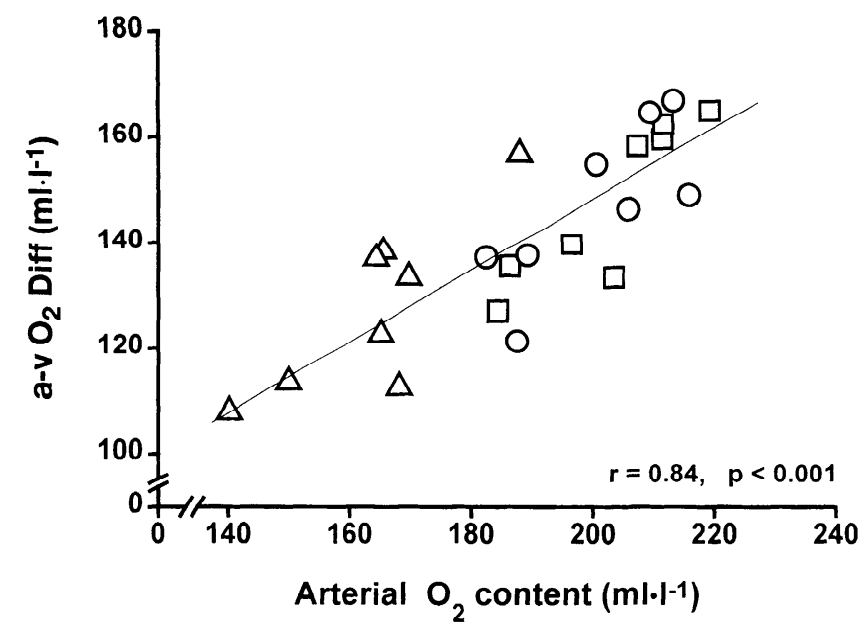

Fig. 8. Individual values for femoral a-v $\mathrm{O}_{2}$ Diff in relation to arterial $\mathrm{O}_{2}$ content at peak effort under normoxia and hypoxia. $\square, \mathrm{FI}_{\mathrm{O}_{2}} 0.21$; $\mathrm{O}, \mathrm{FI}_{\mathrm{O}_{2}} 0.16 ; \triangle, \mathrm{Fi}_{\mathrm{O}_{2}} 0.11$.

explaining a large $\mathrm{O}_{2}$ extraction by muscle in hypoxia. In addition to $\mathrm{Ca}_{\mathrm{O}_{2}}$ (Fig. 5), several other factors can play a role, such as $\mathrm{Pa}_{\mathrm{O}_{2}}$, mean transit time (MTT), and $\mathrm{pH}$ (arterial and/or femoral venous). Of these, $\mathrm{Ca}_{\mathrm{O}_{2}}$, $\mathrm{Pa}_{\mathrm{O}_{2}}$, and $\mathrm{pH}$ were similar in the present three subjects, with a mean $\dot{\mathrm{V}}_{2 \max }$ of $66 \mathrm{ml} \cdot \mathrm{kg}^{-1} \cdot \mathrm{min}^{-1}$ and two subjects having only $41 \mathrm{ml} \cdot \mathrm{kg}^{-1} \cdot \mathrm{min}^{-1}$. Because of a rather low LBF per unit knee-extensor muscle in the untrained subjects, their MTT was generally higher, contributing to a similar high $\mathrm{O}_{2}$ extraction as observed in the well-trained subjects. The three subjects in between $\left(\mathrm{V}_{O_{\max }} 51 \mathrm{ml} \cdot \mathrm{kg}^{-1} \cdot \mathrm{min}^{-1}\right)$ had a lower $\mathrm{O}_{2}$ extraction $(\sim 10 \%)$ that could be explained by the lower $\mathrm{Ca}_{\mathrm{O}_{2}}$. Their lower MTT compared with the other subjects may also have contributed. This pattern for the three subgroups was very similar in all three conditions. Returning to why $\mathrm{O}_{2}$ still remains, to such a large extent, in the femoral vein blood draining the kneeextensor muscles, the MTTs could play a role. In the present study, they were estimated to be as low as between 400 and $600 \mathrm{~ms}$, with the longest time at $\mathrm{FI}_{\mathrm{O}_{2}}$ 0.11 . The role of $\mathrm{pH}$ is also critical for the unloading of $\mathrm{O}_{2}$ from the hemoglobin molecule. With more lactate being produced during hypoxic exercise, very low blood $\mathrm{pH}$ could have been anticipated at peak effort. The $\mathrm{pH}$ values are low (7.15-7.25) but are not significantly different among conditions, although the $\mathrm{pH}$ tended to be higher at $\mathrm{FI}_{\mathrm{O}_{2}}$ 0.11. The reason is that the pronounced hyperventilation kept the $\mathrm{Pfv}_{\mathrm{CO}_{2}}$ low. In ordinary bicycle work, $\mathrm{Pfv}_{\mathrm{CO}_{2}}$ approaches 100 Torr but is $<60$ Torr in the present study at peak effort at $\mathrm{FI}_{\mathrm{O}_{2}} 0.11$. As a result, although the hyperventilation was high, arterial $\mathrm{PCO}_{2}$ was not exceptionally low.

At rest, $\mathrm{CO}$ and $\mathrm{HR}$ increase with acute hypoxia, whereas at maximal whole body exercise, no change is reported in $\mathrm{CO}$ and $\mathrm{HR}(5,19,22)$, but others have observed a decrement in peak HR $(6,12)$. In our study, $\mathrm{CO}$ at peak effort was lower in all subjects at $\mathrm{FI}_{\mathrm{O}_{2}}$ 0.11 (mean decrease $2.32 \mathrm{l} / \mathrm{min}$ ), with the decrease being largely due to lower exercise SV. We also observed individual variability in peak HR responses, as previ- ously noted $(3,22)$, resulting in no net change in average $\mathrm{HR}$ at peak effort. In contrast, $\mathrm{SV}$ at peak effort was uniformly lower, representing an average reduction of $\sim 16 \mathrm{ml}$, which explains the $11 \%$ drop observed in $\mathrm{CO}$. As with the apparent reduction in LBF at peak effort, when $\mathrm{CO}$ is considered in terms of workload, the reduction disappears. One possible explanation for the lower SV at peak effort with hypoxia could be a response similar to that found after successive bouts of exercise preceded by heavier work (9). The mechanism for the decrease in SV was not identified in that study, although the authors speculate that the decrease was secondary to changes in myocardial function. A more recent work (7) suggested that SV may decrease after exhaustive work due to $\beta$-receptor downregulation. Whether a similar response occurs and is enhanced by acute hypoxia is not known. What may speak against this being the explanation is that, in ordinary bicycle work during acute hypoxemia, SV is subnormal at light to moderate exercise and HR is up to $160-170$ beats/ min, but at peak exercise, when the sympathetic drive is at its highest and maximal $\mathrm{HR}$ is reached, $\mathrm{SV}$ is normalized. The two-legged knee-extension exercise only brings the HR up to just below 160 beats/min at peak effort, suggesting that far from maximal sympathetic drive to the heart has been achieved. The lowering of $\mathrm{SV}$ is likely to be elicited by the lower $\mathrm{Pa}_{\mathrm{O}_{2}}$ affecting the myocardium directly because the coronary blood flow can markedly increase and thus compensate for the lower $\mathrm{Ca}_{\mathrm{O}_{2}}$ and thereby maintain $\mathrm{O}_{2}$ delivery to the myocardium (15). Moreover, in a study (13) where $\mathrm{Ca}_{\mathrm{O}_{2}}$ was acutely reduced by withdrawal of whole blood and substituted with albumin, SV was maintained.

By using $\mathrm{FI}_{\mathrm{O}_{2}} 0.16$ in addition to $\mathrm{FI}_{\mathrm{O}_{2}}$ 0.11, we hoped to see graded responses that were directly attributable to hypoxia. Despite the significant decrement in $\mathrm{Pa}_{\mathrm{O}_{2}}$, $\mathrm{Sa}_{\mathrm{O}_{2}}$, and $\mathrm{Ca}_{\mathrm{O}_{2}}$ at $\mathrm{FI}_{\mathrm{O}_{2}} 0.16$ (Fig. 1), only minor cardiovascular, pulmonary, or metabolic responses were observed at this modest degree of hypoxemia, especially at submaximal exercise. Peak power output and leg $\dot{\mathrm{V}}_{2}$ were, however, reduced by $\sim 10 \%$ because the $\mathrm{LBF}$ response was similar comparing normoxia with $\mathrm{FI}_{\mathrm{O}_{2}} 0.16$. The femoral venous lactate and arterial $\mathrm{pH}$ values were also similar at submaximal and peak work. This finding of minimal effects of $\mathrm{FI}_{\mathrm{O}_{2}} 0.16$ and the resultant $\mathrm{Pa}_{\mathrm{O}_{2}}$ of $\sim 70$ Torr suggests that this degree of hypoxemia is within the range of cardiopulmonary accommodation in healthy, young individuals exercising with a limited proportion of muscle mass.

The final point to be discussed relates to why the subjects fatigue and especially why the peak power output is diminished in hypoxia. One hypothesis is that $\mathrm{Pa}_{\mathrm{O}_{2}}$ acts directly on the brain (4). This is primarily thought to play a role in chronic hypoxia and exercise with a large fraction of the muscle mass. It could, however, also be at work in our study as well as in the studies of Rowell et al. (18) and Richardson et al. (17) because extreme hyperventilation during hypoxia is proposed to be a possible crucial additive factor inhibiting sympathetic outflow. There may be signs of this in 
the present study. Despite the strong hypoxic drive, the peak HR was not elevated and SV was reduced compared with normoxia. With no elevation in $\mathrm{CO}$ and only a minor or absent redistribution of the $\mathrm{CO}$ to the legs, $\mathrm{O}_{2}$ delivery could not be maintained at peak effort and power output was reduced accordingly. In the scheme put forth by Bigland-Ritchie and Vollestad (4), it was further proposed that the motor cortex is inhibited as well, centrally reducing the motor drive to the muscles. Against such a mechanism to be at play in hypoxia is the finding of maintained unilateral forearm maximal isometric strength during exhausting ordinary bicycle exercise with severe hypoxia (20). Thus the muscles can transiently produce high force, but it cannot be maintained due to limited aerobic metabolism.

In summary, our findings allow a consensus on LBF compensating for a low $\mathrm{Ca}_{\mathrm{O}_{2}}$ during submaximal exercise, thereby maintaining $\mathrm{O}_{2}$ delivery during hypoxemia, resulting in an $\sim 25 \%$ reduction in $\mathrm{Ca}_{\mathrm{O}_{2}}$. A similar consensus can be drawn regarding the apparent inability for such compensation at peak exhaustive exercise. For reasons not yet explained, LBF does not increase to compensate for hypoxemia at peak effort in the two-legged knee-extension exercise model. This occurs despite the cardiovascular system not being taxed maximally. We are left with intriguing questions regarding the regulation and limitation of peripheral blood flow in maximally exercising muscle.

This study was made possible by Danish National Research Foundation Grant 50114.

M. D. Koskolou was also supported by the University of Athens, Greece, and J. A. L. Calbet was supported by the University of Las Palmas de Gran Canaria, Canary Islands, Spain.

Present addresses: M. D. Koskolou, Dept. of Physical Education and Sport Science, Univ. of Athens, Athens, Greece; J. A. L. Calbet, Dept. of Physical Education, Univ. of Las Palmas de Gran Canaria, Canary Islands, Spain.

Address for reprint requests: M. Koskolou, Rigshospitalet, CMRC, section 7652, Tagensvej 20, DK-2200 Copenhagen N, Denmark.

Received 21 November 1996; accepted in final form 14 January 1997.

\section{REFERENCES}

1. Andersen, P., and B. Saltin. Maximal perfusion of skeletal muscle in man. J. Physiol. (Lond.) 366: 233-249, 1985.

2. Asmussen, E., and C. F. Consolazio. The circulation in rest and work on Mount Evans $(4,300 \mathrm{~m})$. Am. J. Physiol. 132: 555-563, 1941.

3. Åstrand, P. O., and I. Åstrand. Heart rate during muscular work in man exposed to prolonged hypoxia. J. Appl. Physiol. 13: $75-80,1958$.

4. Bigland-Ritchie, B., and N. K. Vollestad. Hypoxia and fatigue: how are they related? In: Hypoxia. The Tolerable Limits, edited by J. R. Sutton, C. S. Houston and G. Coates. Indianapolis, IN: Benchmark, 1988, p. 315-328.
5. Bouissou, P., F. Peronnet, G. Brisson, R. Helie, and M. Ledoux. Metabolic and endocrine responses to graded exercise under acute hypoxia. Eur. J. Appl. Physiol. Occup. Physiol. 55: 290-294, 1986.

6. Dill, D. B., L. G. Myhre, E. E. Phillips, and D. K. Brown. Work capacity in acute exposures to altitude. J. Appl. Physiol. 21: 1168-1176, 1966.

7. Eysmann, S. B., E. Gervino, D. E. Vatner, S. E. Katz, L. Decker, and P. S. Douglas. Prolonged exercise alters $\beta$-adrenergic responsiveness in healthy sedentary humans. J. Appl. Physiol. 80: 616-622, 1996.

8. Harder, D. R., J. Narayanan, E. K. Birks, J. F. Liard, J. D. Imig, J. H. Lombard, A. R. Lange, and R. J. Roman. Identification of a putative microvascular oxygen sensor. Circ. Res. 79: 54-61, 1996.

9. Hartley, L. H., and B. Saltin. Reduction in stroke volume and increase in heart rate after a previous heavier submaximal workload. Scand. J. Clin. Lab. Invest. 22: 217-223, 1968.

10. Jones, P. R. M., and J. Pearson. Anthropometric determination of leg fat and muscle plus bone volumes in young male and female adults. J. Physiol. (Lond.) 204: 63P-66P, 1969.

11. Klausen, K. Cardiac output in man at rest and work during and after acclimatization to 3,800 m. J. Appl. Physiol. 21: 609-616, 1966.

12. Klausen, K. Exercise under hypoxic conditions. Med. Sci. Sports 1: 43-49, 1969.

13. Koskolou, M., R. C. Roach, J. A. L. Calbet, and B. Saltin. Cardiovascular adjustments in man to low arterial oxygen content: is oxygen content, saturation or tension the regulator? (Abstract). J. Physiol. (Lond.) 495: 137P, 1996.

14. Marshall, J. M. Skeletal muscle vasculature and systemic hypoxia. News Physiol. Sci. 10: 274-280, 1995.

15. Paridon, S. M., J. T. Bricker, W. J. Dreyer, M. Reardon, E. O. Smith, C. J. Porter, L. Michael, and D. J. Fisher. The effects of hypoxemia on myocardial blood flow during exercise. Pediatr. Res. 25: 280-284, 1989.

16. Qu, Z., J. L. Andersen, and S. Zhou. Visualization of capillaries in human skeletal muscle. Histochem. Cell. Biol. 107: 169$174,1997$.

17. Richardson, R. S., D. S. Knight, D. C. Poole, S. S. Kurdak, M. C. Hogan, B. Grassi, and P. D. Wagner. Determinants of maximal exercise $\mathrm{V}_{2}$ during single leg knee-extensor exercise in humans. Am. J. Physiol. 268 (Heart Circ. Physiol. 37): H1453H1461, 1995.

18. Rowell, L. B., B. Saltin, B. Kiens, and N. J. Christensen. Is peak quadriceps blood flow in humans even higher during exercise with hypoxemia? Am. J. Physiol. 251 (Heart Circ. Physiol. 20): H1038-H1044, 1986.

19. Saltin, B., R. F. Grover, C. G. Blomqvist, L. H. Hartley, and R. L. Johnson. Maximal oxygen uptake and cardiac output after 2 weeks at 4,300 m. J. Appl. Physiol. 25: 400-409, 1968.

20. Savard, G. K., N. H. Areskog, and B. Saltin. Maximal muscle activation is not limited by pulmonary ventilation in chronic hypoxia. Acta Physiol. Scand. 157: 187-190, 1996.

21. Skinner, M. R., and J. M. Marshall. Studies on the roles of ATP, adenosine and nitric oxide in mediating muscle vasodilatation induced in the rat by acute systemic hypoxia. J. Physiol. (Lond.) 495: 553-560, 1996.

22. Stenberg, J., B. Ekblom, and R. Messin. Hemodynamic response to work at simulated altitude, 4,000 m. J. Appl. Physiol. 21: 1589-1594, 1966. 